\title{
Discovery of sapphirine in East
} Greenland

\author{
C. Kent Brooks
}

An occurrence of sapphirine is described from the Kronprins Frederik Bjerge (about $67^{\circ} \mathrm{N}$ ) in East Greenland. It occurs in an assemblage with phlogopite, spinel and orthopyroxene in a thin band in quartzo-feldspathic gneisses of granulite facies but may well be much more widespread in the area.

Sapphirine was first described from the Fiskenæsset region of southern West Greenland in 1808 by Giesecke (1910). It was formerly regarded as a rare mineral, but in recent years it has been reported with increasing frequency from amphibolite and granulite facies metamorphic terrains and even in xenoliths from kimberlites. In West Greenland sapphirine has been described by Ramberg (1948), Bøggild (1953) and Sørensen (1955). It occurs most prominently along the margins of the Fiskenæsset layered anorthosite complex in spectacular assemblages together with, among other minerals, kornerupine. ruby corundum and högbomite, and has been well documented by Herd (1972, 1973), Friend \& Hughes (1981), Friend (1982), Ackermand et al. (1983) and Williams (1984).

During field work by the Geodxtisk Institut, samples of mica-rich rock containing centimetre-sized crystals of a deep blue, erosion-resistant mineral were brought back to the base camp by T. Hauge Andersson, who had previously worked in the Fiskenæsset area and was familiar with sapphirine. The locality was subsequently visited by this author and further material was collected. It is situated on an eastward-oriented spur of the side of a high nunatak in an exceedingly remote area in the nunataks of Kronprins Frederik Bjerge (figs 1 and 2) and the exact locality is not easy to locate on existing maps (Geodatisk Institut 1:250 000, published 1974 after an original of 1933). However, the position was fixed by means of TRANSIT observations to $67^{\circ} 22^{\prime} 03^{\prime \prime} \mathrm{N}$, $34^{\circ} 23^{\prime} 23^{\prime \prime} \mathrm{W}$ and this is believed to be accurate to less than $1^{\prime \prime}$ in both latitude and longtitude.

At a distance, the rocks appear massive and brown in colour, characteristics which are taken to indicate that they are in granulite facies. Prior to the visit of GGU in 1986, only the Westminster East Greenland Expedition 1978 (Woolley et al. 1978) had visited this region and they reported massive gneisses with feldspathic banding north of $66^{\circ} 50^{\prime} \mathrm{N}$ and occasional large recumbent folds.
In the inland part of the area they reported massive granite with large sheets of basic rock. In addition four occurrences of "distinctive litholigies, probably supracrustal in origin" were reported. Most of the rocks are probably of Archaean age; in the south they are affected by Proterozoic deformation where retrogression to amphibolite facies gives them a greyish colour.

Sapphirine occurs in a thin. less than $1 \mathrm{~m}$ thick, band in the quartzo-feldspathic gneisses. This band is northward-trending and steeply-dipping and is followed along one side by a pseudotachylite of about $2 \mathrm{~cm}$ thickness and concordant with the foliation. Sapphirine forms crystals up to about $1 \mathrm{~cm}$ in size which stand out on the weathered surface due to their resistance to weathering.

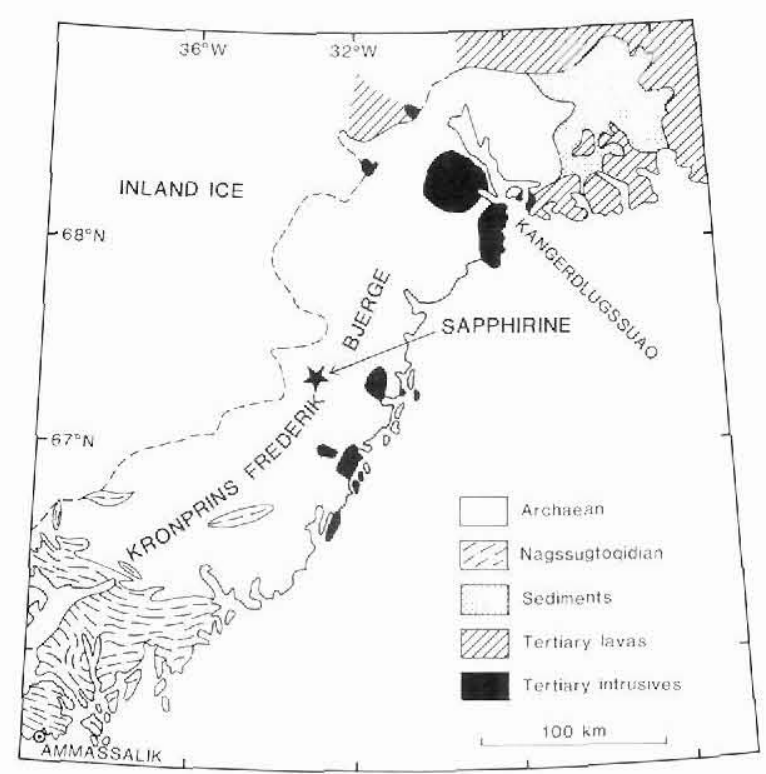

Fig. 1. Part of East Greenland showing regional geology after Myers et al. (1980) and location of the sapphirine locality. Broken line marks innermost extent of nunataks. 


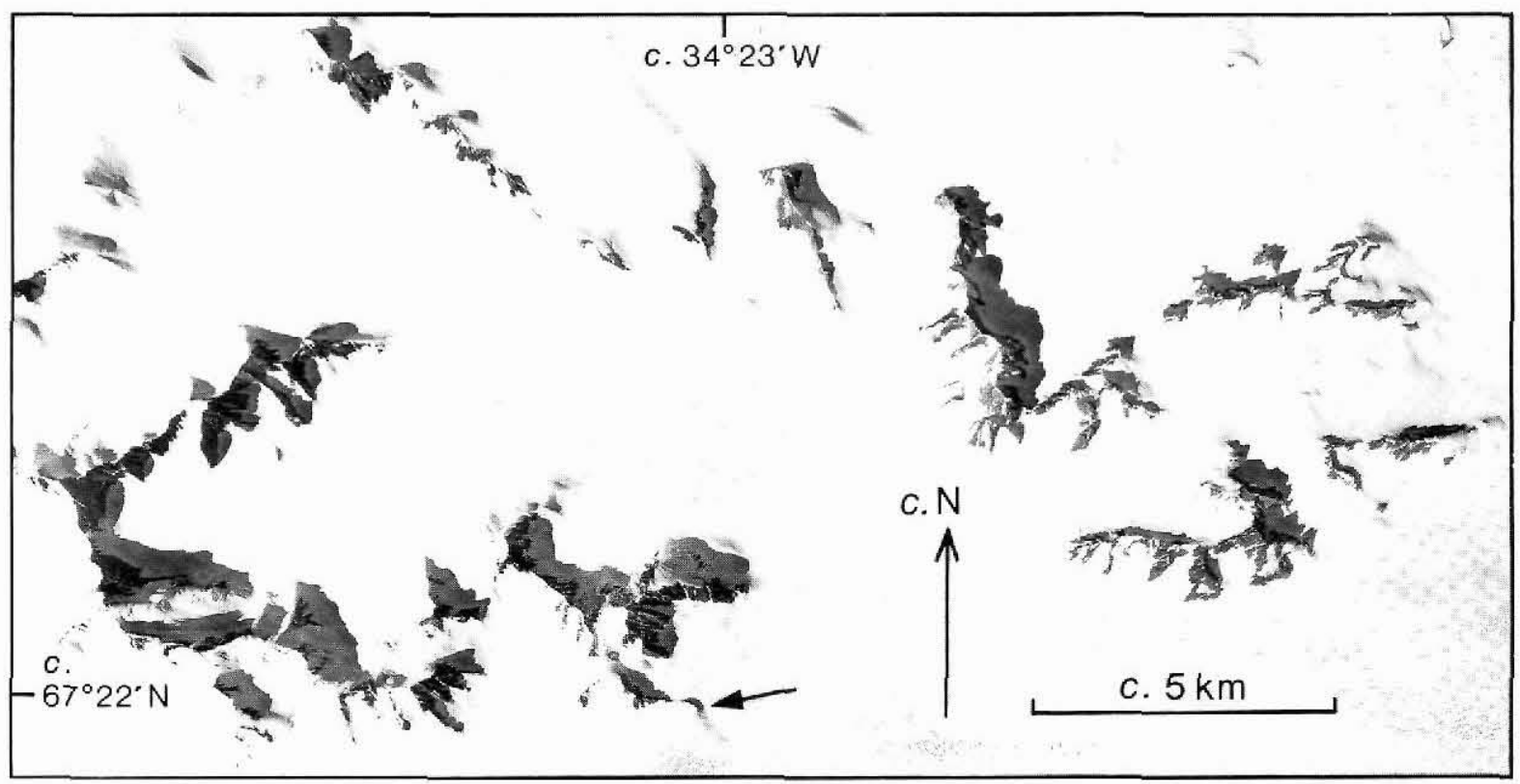

Fig. 2. Aerial photograph of the locality (shown by arrow).

It is of a deep, prussian blue colour and is accompanied by mica and a straw-coloured, bladed mineral, subsequently identified as orthopyroxene. Mica is the most voluminous mineral in all samples, but sapphirine may reach over $30 \%$ in some. Microscopic examination shows that green spinel is also an important constituent. Sapphirine is pale blue in thin section, in contrast to the material described by Williams (1984) from Fiskenæsset, which was stated to be colourless in thin section. Microprobe analyses of the main minerals are shown in Table 1.

The formula for sapphirine is generally given as: $(\mathrm{Mg}, \mathrm{Fe})_{8 \times}(\mathrm{Al}, \mathrm{Fe})_{\mathrm{x}}{ }^{\mathrm{V} I}\left(\mathrm{Si}_{6 \cdot \mathrm{x}}, \mathrm{Al}_{\mathrm{x}}\right)^{\mathrm{IV}} \mathrm{O}_{20}$ with the major substitution being $\mathrm{MgSi} \rightleftharpoons{ }^{\mathrm{V}} \mathrm{Al}{ }^{\mathrm{IV}} \mathrm{Al}$ (Higgins et al., 1979). The composition given in Table 1 is unremarkable and appears to conform to this substitution. It is somewhat more Fe-rich than most Fiskenæsset samples quoted by Herd (1973) with an $\mathrm{Mg} /(\mathrm{Mg}+\mathrm{Fe})$ ratio of 0.87 as against 0.96-90, although Williams (1984) reported an example with this ratio of 0.84 . Calculation of $\mathrm{Fe}^{3+}$ and $\mathrm{Fe}^{2+}$ by stoichiometry using the procedure described by Higgins et al. (1979) shows it to be unusually oxidized although the significance of this is unclear.

Spinel is close to its ideal composition, while phlogopite is very $\mathrm{Mg}$-rich with a high $\mathrm{Al}_{2} \mathrm{O}_{3}$ content and a slight $\mathrm{K}_{2} \mathrm{O}$ deficiency. The orthopyroxene is a bronzite, again with a lower $\mathrm{Mg} / \mathrm{Fe}$ ratio than those of Fiskenæsset. It has a high $\mathrm{Al}_{2} \mathrm{O}_{3}$ content, perhaps indicative of a high pressure of formation and typical of orthopyro-
Table 1. Minerals of sapphirine granulite, Kronprins Frederik Bjerge, East Greenland

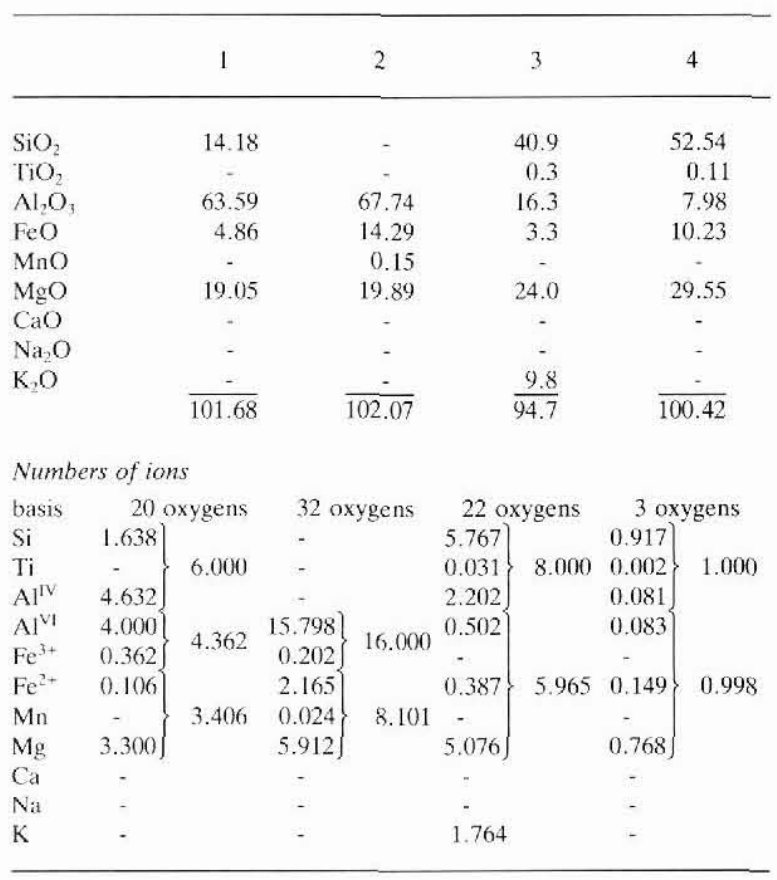

GGU sample no. 312068 .

1. Sapphirine: $(\mathrm{MgFe})_{2} \mathrm{Al}_{4} \mathrm{O}_{6}\left[\mathrm{SiO}_{4}\right]$, calculated by method of Higgins et al. (1979).

2. Spinel: $(\mathrm{MgFe})_{8} \mathrm{Al}_{16} \mathrm{O}_{32}$

3. Phlogopite: $\mathrm{K}_{2}(\mathrm{MgFe})_{6}\left[\mathrm{Si}_{6} \mathrm{Al}_{2} \mathrm{O}_{20}\right](\mathrm{OH}, \mathrm{F})_{4}$.

4. Aluminous orthopyroxene: $(\mathrm{MgFe}) \mathrm{SiO}_{3}$ 
xenes from granulites and high pressure megacrysts in alkali basalt and kimberlites.

Calculation of distribution coefficients for partitioning of $\mathrm{Fe}^{2+} / \mathrm{Mg}$ between sapphirine and spinel and orthopyroxene give values of 0.17 and 0.33 which is appreciably less than the values of 0.28 and 0.65 given by Higgins et al. (1979), but again the significance of this is unknown. There is no suggestion from the texture that this is a disequilibrium assemblage.

The compositions of the minerals indicate that this is an aluminous, subsilicic and highly magnesian assemblage which is typical for the occurrence of sapphirine. Whereas such compositions could arise from ultrabasic igneous rocks, the small extent of this occurrence reinforces the idea that the protolith was sedimentary.

As the geology of this area is so poorly known, it is likely that this sapphirine-bearing assemblage is not unique and future workers are urged to be aware of this likelihood.

Acknowledgements. T. Hauge Andersson is congratulated for his observational powers and thanked for bringing this occurrence of sapphirine to the author's attention. Mineral analyses were made by J. G. Rønsbo using the Jeol microprobe at the Institute of Mineralogy, University of Copenhagen, which is financed by the Danish Natural Science Research Foundation. 